\title{
Linear polymerization shrinkage of Bulk Fill resins
}

\section{Contração linear de polimerização das resinas Bulk Fill}

\author{
Tereza Cristina Correia* \\ Rodivan Braz da Silva** \\ Manassés Tercio Vieira Grangeiro*** \\ Helen Tayná Noca de Souza ${ }^{* * * *}$ \\ Lorem Krsna de Morais Sousa ${ }^{* * * * *}$ \\ Diala Aretha de Sousa Feitosa ${ }^{* * *+*}$
}

\section{Abstract}

Objective: the objective of the present study was to analyze the polymerization shrinkage gap of different composite resins. Methods: four commercial brands $(n=5)$ were tested: Z350 (3M/ESPE); Filtek Bulk Fill (3M/ESPE); Surefill (Dentsply); Xtra Base (Voco). Increments of composite resins were inserted into a circular metal matrix of $7 \mathrm{~mm}$ internal diameter and $4 \mathrm{~mm}$ high and pressed by two glass plates supported on polyester strips. After photoactivation with a Optilight Plus device (Gnatus), with light intensity of $1000 \pm 10 \mathrm{~mW} / \mathrm{cm}^{2}$, the test samples were polished and $24 \mathrm{~h}$ later, taken to the scanning electron microscope for analysis of the polymerization shrinkage gap, measured at 4 points in the sample $(3,6$, 9, and 12 o'clock). The data were analyzed by analysis of variance (Anova one-way). Results: the highest mean of polymerization shrinkage gap was observed for Filtek Z350 (3M/ESPE), while the lowest mean of gap was found for Xtra Base (Voco) brand, with significant differences between the groups. Conclusion: the inorganic filler content and different associations in the organic matrices interfered expressively in the polymerization shrinkage gap.

Keywords: Bulk Fill resins. Composite resins. Polymerization shrinkage.

\section{Introduction}

The dimensional shrinkage of the restorative material could modify the composite/tooth interface, resulting in a true hermetic seal that would ensure restorations without infiltrations and with perfect marginal adaptations ${ }^{1}$. However, this is the greatest challenge of the current adhesive dentistry, since most of these materials cannot achieve excellence in these results. The polymerization shrinkage is obtained through the conversion of monomeric molecules into a polymer network, leading to a greater intermolecular proximity ${ }^{2}$.

The volumetric shrinkage, which is a result of the development of an internal stress, occurs largely in a range of 1.5 to $5 \%$, as product of the rigid nature of the cross-linked polymeric matrix that is formed $^{3}$. The formation of this stress implies in the imperfection of the margins of the restorations with composite resin, which affects significantly its clinical longevity ${ }^{3}$. The possible partial transmission of this shrinkage stress to the adhesive interface compromises the marginal integrity and results in postoperative sensibility, as well as in a greater susceptibility of micro infiltration of the restorations ${ }^{4}$.

Thus, it has been previously reported that the stress generated by the polymerization shrinkage directly triggers clinical consequences in the restoration $^{5}$. Therefore, several studies have been carried out to evaluate the measurement, generation and characterization of this stress, as well as the improvement of the physical, chemical and mechanical properties of the composites ${ }^{3,4}$.

PhD, Department of Dentistry, University of Pernambuco, Recife, Pernambuco, Brazil.

PhD, Department of Dentistry, University of Pernambuco, Recife, Pernambuco, Brazil.

Academic, Department of Dentistry, Centro Universitário Doutor Leāo Sampaio, Juazeiro do Norte, Ceará, Brazil.

Academic, Department of Dentistry, Centro Universitário Doutor Leāo Sampaio, Juazeiro do Norte, Ceará, Brazil.

Academic, Department of Dentistry, Centro Universitário Doutor Leāo Sampaio, Juazeiro do Norte, Ceará, Brazil.

* PhD, Department of Dentistry, Centro Universitário Doutor Leāo Sampaio, Juazeiro do Norte, Ceará, Brazil. 
Increasingly importance has been given to the development of novel composite resins, especially the Bulk Fill composites, which has shown promising results. These composites are indicated for base and restoration of posterior teeth to obtain low shrinkage and a unique increment in the cavity with volume of $4 \mathrm{~mm}^{1}$. Therefore, it is important to evaluate the polymerization shrinkage of this material compared to conventional composites.

Resins of diverse classifications and compositions contract in distinct ways after photoactivation. Therefore, it is extremely important to evalu- ate the behavior of these materials in the complex process of polymerization contraction. Thus, the objective of the present study was to analyze the polymerization contraction gap of diverse types of Bulk Fill composites and a conventional nanoparticulate resin.

\section{Methods}

The composite resins analyzed and their characteristics are shown in the Table 1.

Table 1 - Commercial names (manufacturers), classification, composition, manufacturing lots and photoactivation time of the composite resins utilized

\begin{tabular}{|c|c|c|c|c|c|c|}
\hline Product & Classification & Resin matrix & Filler & $\%$ Volume & $\begin{array}{l}\text { Manufacturer } \\
\text { (lot number) }\end{array}$ & $\begin{array}{c}\text { Photoactivation } \\
\text { Time }\end{array}$ \\
\hline Z350 (3M/ESPE) & Nanofilled & $\begin{array}{l}\text { TEGDMA, UDMA, } \\
\text { Bis-EMA, Bis-GMA }\end{array}$ & $\begin{array}{l}\mathrm{SiO}_{2}(20 \mathrm{~nm}), \mathrm{ZrO}_{2}(4-11 \\
\mathrm{nm}) \text {, aggregated } \mathrm{ZrO}_{2} / \\
\mathrm{SiO}_{2} \text { cluster }(0.6-10 \mu \mathrm{m}\end{array}$ & $59,5 \%$ & N569664 & $20 \mathrm{~s}$ \\
\hline $\begin{array}{l}\text { Filtek Bulk Fill (3M/ } \\
\text { ESPE) }\end{array}$ & Flowable & $\begin{array}{l}\text { Bis-GMA, BisEMA, } \\
\text { UDMA and Procrylat } \\
\text { monomers }\end{array}$ & $\begin{array}{l}\text { 10nm to } 3.5 \mu \mathrm{m} \text { zirconia/ } \\
\text { sílica filler, } 100 \mathrm{~nm} \text { to } 5.0 \\
\mu \mathrm{m} \text { ytterbium trifluoride } \\
\text { filler }\end{array}$ & $64,3 \%$ & N473386 & $20 \mathrm{~s}$ \\
\hline Surefill (Dentsply) & Flowable & $\begin{array}{l}\text { SDR patented UDMA, } \\
\text { TEGDMA, EBPDMA }\end{array}$ & $\begin{array}{l}\text { Baruim and strontium } \\
\text { alumino-fluoro-silicate } \\
\text { glass }\end{array}$ & $68 \%$ & 130103 & $20 \mathrm{~s}$ \\
\hline Xtra Base (Voco) & Flowable & $\begin{array}{l}\text { Bis-GMA, UDMA, } \\
\text { TEGDMA }\end{array}$ & $\begin{array}{l}2-3 \mu \mathrm{m} \text { Ba B Al Si glass } \\
\text { filler }\end{array}$ & $75 \%$ & 1341137 & $20 \mathrm{~s}$ \\
\hline
\end{tabular}

* Bis-GMA (bisphenol-A diglycidylether methacrylate), Bis-EMA (bisphenol-A polyethethylene glycol diether dimethacrylate), UDMA (urethane dimethacrylate), TEGDMA (triethylene glycol dimethacrylate), EBPDMA (ethoxylated bisphenol-A-dimethacrylate).

Source: authors.

For the preparation of the specimens, circular metal matrices with internal diameter of $7.0 \mathrm{~mm}$, external diameter of $11.5 \mathrm{~mm}$ and $4.0 \mathrm{~mm}$ of height were used (Figure 1).
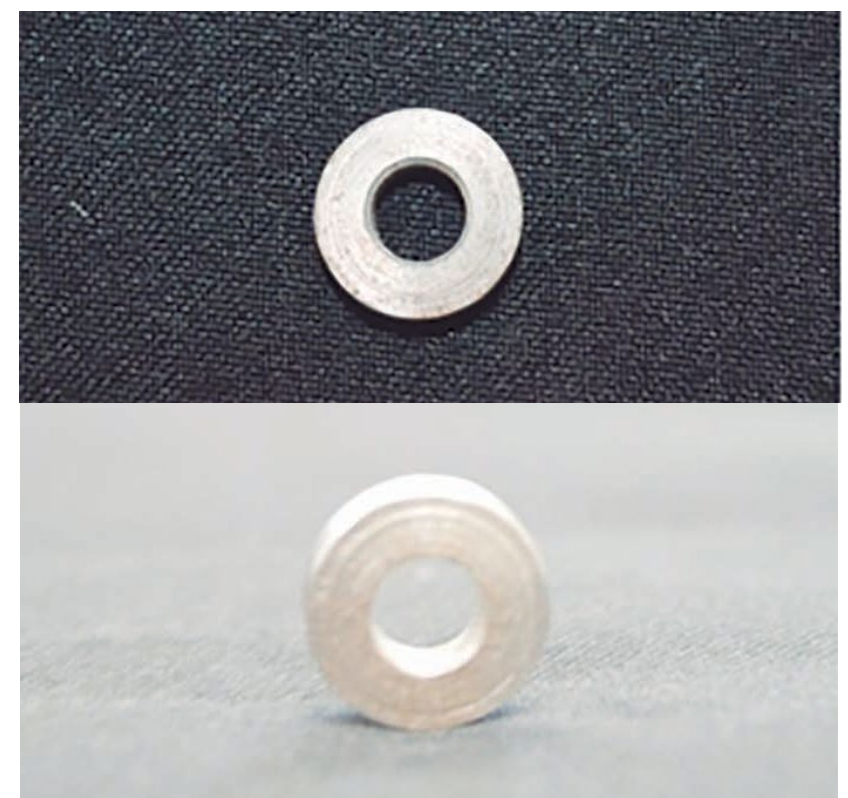

Figure 1 - Metal matrix

Source: authors.
Each matrix was placed on a polyester strip, and then, on a glass plate. The restorative composite was inserted into the matrix in a single increment and the surface was covered with another polyester strip and pressed with a glass plate for 30 s to get a flat surface, standardize the volume of material within the matrix and minimize surface irregularities of the composite. Then, the plate was removed for photoactivation.

The composite resins were photoactivated according to the recommendation of the manufacturer of the respective products $(20 \mathrm{~s})$, with the use of the Optilight device (Figure 2a) (Gnatus Equipamentos Médico-Odontológicos, Ribeirão Preto, SP, Brazil). The intensity of light was measured in each specimen using a radiometer (Gnatus, Ribeirão Preto, SP, Brazil) at $1000 \pm 10 \mathrm{~mW} / \mathrm{cm}^{2}$, so that five specimens were made for each composite resin trade mark.

After preparation, both surfaces of the specimens were planed and polished with a silicon carbide sandpaper of granulation No. 1200 (Norton S.A., São Paulo, SP, Brazil). Then, the specimens were immersed in an ultrasonic tank for $15 \mathrm{~min}$ to remove the residues. Four markers were then placed on the metal matrix, corresponding to $3,6,9$ and $12 \mathrm{~h}$ (Figure 2b) and stored at $37{ }^{\circ} \mathrm{C}$ for $24 \pm 1 \mathrm{~h}$, until measurement of the polymerization shrinkage gap. 


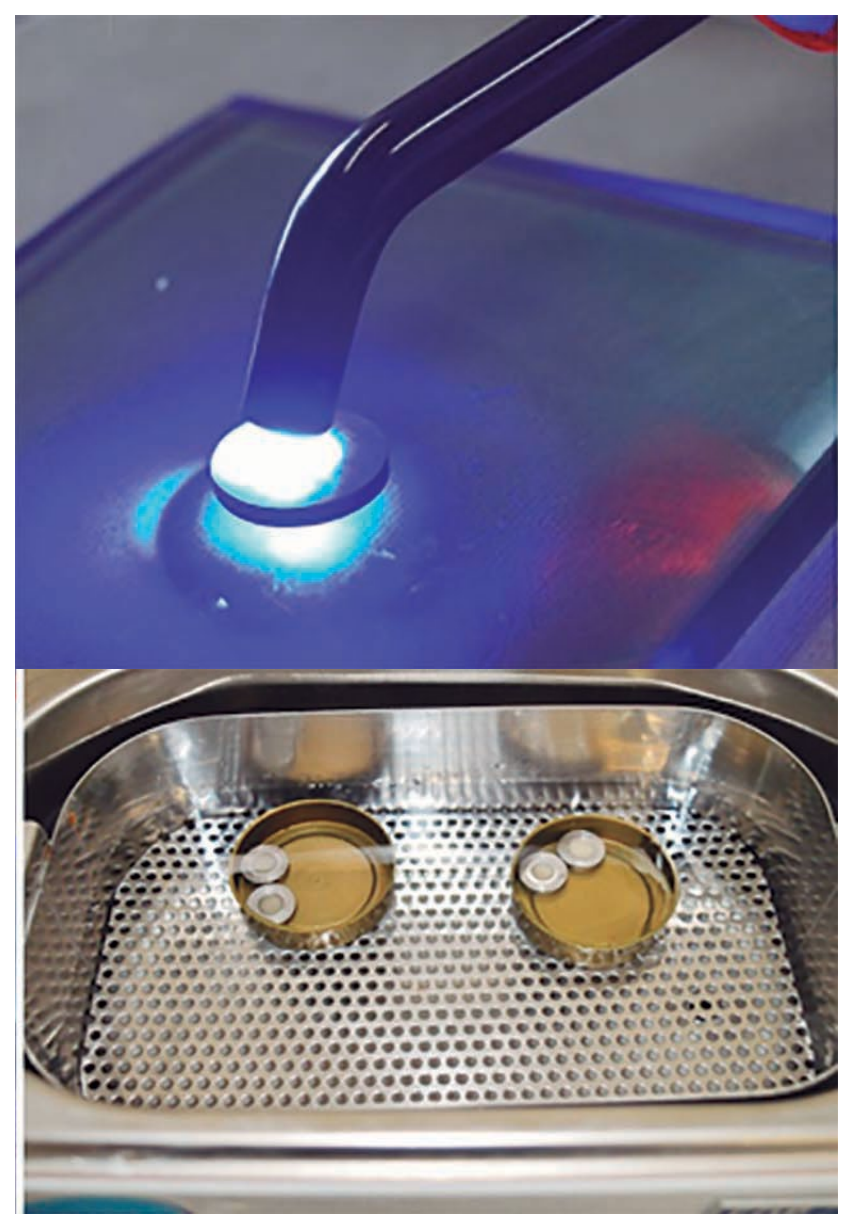

Figure 2 - (a) Photopolymerization of the test specimen; (b) Test specimens in the tank.

Source: authors.

The specimens were attached, metallized (Sputter coater SCD 050 Bal-Tec, Schaan, Liechtenstein), fixed in metallic stubs with carbon tape and measured by a scanning electron microscopy (JEOL-JSM 5900/Japan). The readings of the measurements were performed at the four points mentioned with a magnification of $3000 \mathrm{x}$, using as reference the gap formed between the restorative material and the matrix.

The images were analyzed and the values of the measurement of the gap width were obtained in micrometres $(\mu \mathrm{m})$ using the Image $\mathrm{J}$ software (Image Processing and Analysis in Java) and arithmetic means of each specimens were calculated. Of note, the readings were performed on the top surface of the specimens, that is, on the irradiated region closest to the photopolymerizer. The data were analyzed by analysis of variance (Anova one-way) and Tukey $(\mathrm{p}<0.05)$ with the assistance of statistical software ASSISTAT 7.7.

\section{Results}

Table 2 shows the means and standard deviation for the polymerization contraction gap in all tested resins. The analysis of variance (Anova one-way) demonstrated a statistically significant difference for the resin type factor $(\mathrm{p}<0.0001)$.
Table 2 - Mean and standard deviation of the polymerization shrinkage gap

\begin{tabular}{l|c|c}
\hline \multicolumn{1}{c|}{ Composite resin } & Mean & Standard deviation \\
\hline Z350 (Control) & $24,35(\mathrm{~A})$ & 5,98 \\
Filtek Bulk Fill & $11,76(\mathrm{~B})$ & 3,43 \\
Surefill & $7,42(\mathrm{~B})$ & 3,21 \\
Xtra Base & $2,01(\mathrm{C})$ & 1,58 \\
\hline
\end{tabular}

Source: authors.

According to the SEM analysis, the Bulk Fill Xtra base resin presents the lowest polymerization shrinkage (Figure 3).

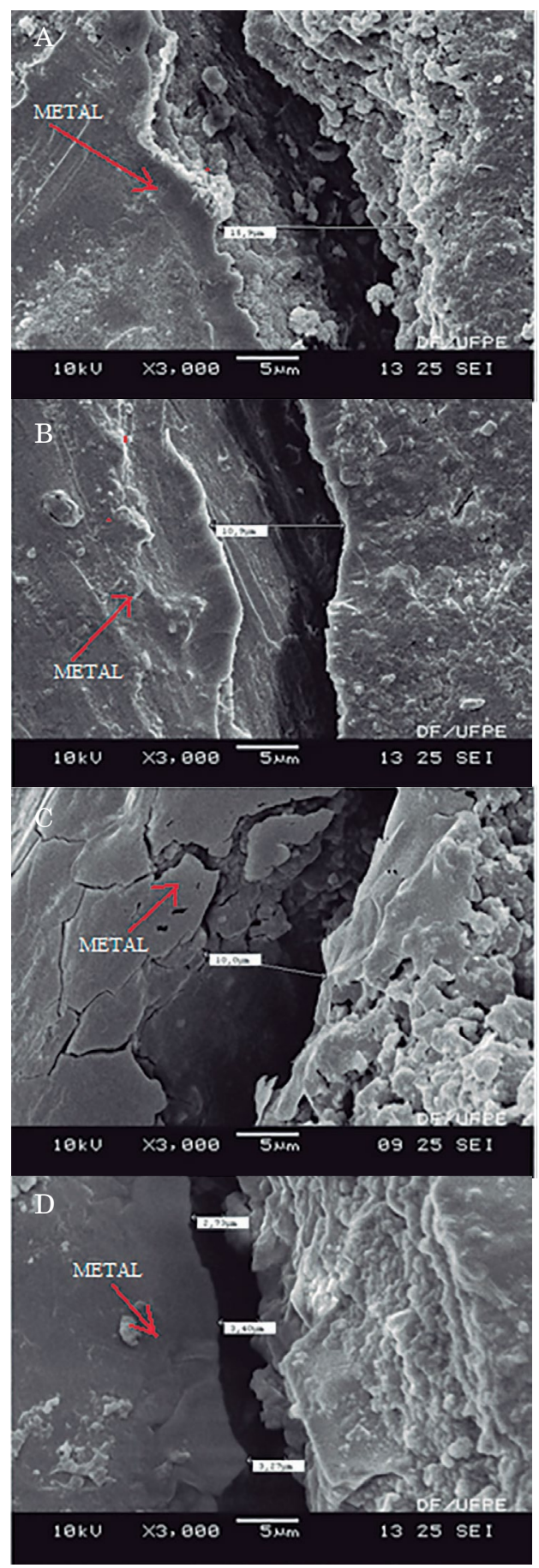

Figure 3 - Evaluation of the scanning electron microscopy of the composite gap: (a) Z350, (b) Filtek Bulk Fill, (c) Surefill, (d) Xtra Base Filtek Bulk Fill.

Source: authors. 


\section{Discussion}

The previously established concept that distinct classifications and compositions of the composite resins contract in different ways throughout the polymerization was confirmed by the present study. This aspect was observed in the microscopic analysis of the contraction gap formed between these composites and their respective metal matrices. The composite resin is considered the material of choice for the repair of damaged or decayed dental structures due to its aesthetic appearance, easy application and adhesion to dental tissues. However, a great challenge in the use of these materials refers to the polymerization shrinkage. Therefore, numerous studies have been carried out, especially in the last two decades, to find out improvements in the mechanical and aesthetic properties of such materials $s^{6,7}$.

The Bulk Fill resins were developed with the aim of obtaining larger increments of up to $4 \mathrm{~mm}$ for deep and wide dental cavities, providing a quicker and easier procedure when compared to the traditional incremental technique ${ }^{1,2,6-8}$. Therefore, it was expected that its behaviour in front the polymerization contraction process would be similar or smaller than the universal composites, a fact observed in the present study. Thus, single increments were used in the tests with all the resins, because the microscopically observed area was the most superficial layer and as such, do not affect the result. The Filtek Bulk Fill (3M/ESPE) and Surefill (Dentsply) resins showed significant differences in the polymerization shrinkage gaps, compared to the Xtra Base (Voco) resin. Therefore, the differences between the formulations of these materials must be emphasized.

The mobility of the Bis-GMA molecule is determined by the reactivity and high molecular weight throughout the polymerization shrinkage, which determines the possibility of dilution to obtain higher conversion values, as well as a compatible viscosity to provide particle filler incorporation to the composite ${ }^{9,10}$.

It is known that each Bis-GMA and Bis-EMA molecule contains two aliphatic carbon double bonds and six aromatic double carbon bonds, that may lead to a lower contraction due to the molecular weight of these monomers, while the TEGDMA and the UDMA have two carbon double bonds aliphatic $^{8}$. The presence of UDMA in the compositions of the composite resins proposes a smaller amount of Bis-GMA in such formulations. Therefore, a higher presence of Bis-GMA reduces conversion and shrinkage of polymerization, as well as it explains the high viscosity observed by the hydroxyl groups and the rigidity provided by the aromatic rings (high molecular weight) allowing a smaller agglomeration of reactive groups. These factors are res- ponsible for the decrease in the mobility necessary for the dissemination of the polymer chain, thus reducing the final conversion ${ }^{11}$. For all studied resins the presence of UDMA was observed, fact that demonstrates a standardization and possible minimization of the polymerization shrinkage.

The TEGDMA monomer presented significantly lower mean values for the polymerization contraction gap ${ }^{12}$. This work demonstrated that only the Filtek Bulk Fill resin did not have this monomer in its composition, which may be a contributing factor to the significant cleavage of the polymerization contraction of this group.

In the present study, the universal resin obtained a higher contraction tension value than the Bulk Fill resin. In fact, fluid resins present, by nature, low modulus of elasticity, which associated with a great fluidity during the initial phase of the polymerization, caused a decrease in the contraction tension, when compared to the conventional resins $^{13}$. In addition, all the Bulk Fill resins evaluated here were of low viscosity, which may have contributed to their low contraction tensions.

Other mechanisms may also contribute for the reduced contraction tensions of Bulk Fill resins, including the appearance of new monomers ${ }^{14}$, as well as the insertion of rheological modulators ${ }^{15}$, such urethane dimethacrylate, which presents promising effects on the decreasing of the voltages generated by the polymerization.

The discrepancies between the polymerization contraction gaps presented by the composites are linked to significant differences in the content of filler particles per volume in the composition of these materials ${ }^{16}$. This factor can be verified in the $\mathrm{X}$-tra Base (Voco) resin, which presented smaller gaps. It presents $75 \%$ of filler particles per volume, a value that is notably higher than the others. Thus, as mentioned above, by increasing the filler content and, therefore, decreasing the flowability, the modulus of elasticity increases in the same proportion and the amount of organic matrix present in the composite is decreased ${ }^{17}$. This fact assists in a reduction in the polymerization contraction ${ }^{18}$.

An increase in the modulus of elasticity of a material can be obtained through a greater incorporation of filler particles, which reduces the amount of organic matrix in the composite and favours a reduction in the polymerization shrinkage ${ }^{18-20}$.

Considering the differences in the composition of the organic matrices of Bulk Fill resins, it is also possible that the contraction gap is related to the presence of the TEGDMA monomer in some formulations, as well as the interactions with other diluent monomers. Finally, further studies are required to characterize the involvement of photoinitiators and patented molecules in this process ${ }^{14,15}$.

In summary, it should be emphasized that the performance and clinical longevity of resin restorations are closely linked to the marginal integrity, 
that is, it is conditioned to lower contraction and stress of polymerization contraction. These factors, in turn, are controlled by the knowledge about the photoactivation units, control of the technique and composition of the materials.

\section{Conclusions}

Differences in the composition and classification of the composite resins contributed to changes in the contraction during the polymerization process. In conclusion:

1. The differences in organic matrices, which were influenced by the presence of the TEGDMA monomer, influenced the contraction tension.

2. The content of particle filler per volume interfered significantly in the polymerization shrinkage gap.

\section{Resumo}

Objetivo: analisar a fenda de contração de polimerização em diferentes compósitos. Métodos: foram testadas quatro marcas comerciais ( $n=5)$ : Z350 (3M/ESPE); Filtek Bulk Fill (3M/ESPE); Surefill (Dentsply); e Xtra Base (Voco). Incrementos de resinas compostas foram inseridos em uma matriz metálica circular de $7 \mathrm{~mm}$ de diâmetro interno e $4 \mathrm{~mm}$ de altura e prensados por duas placas de vidros apoiadas em matrizes de poliéster. Após fotoativação com aparelho Optilight Plus (Gnatus), com intensidade de luz $1000 \pm 10 \mathrm{~mW} / \mathrm{cm}^{2}$, os corpos foram polidos e, 24 horas depois, levados ao microscópio eletrônico de varredura, para análise da fenda de contração de polimerização, medida em 4 pontos na amostra $(3,6$, 9 e 12 horas). Os dados foram avaliados por análise de variância (Anova one-way). Resultado: Filtek Z350 (3M/ ESPE) manifestou a maior medida de fenda de contração de polimerização, já Xtra Base (Voco) apresentou a menor fenda com valores médios significantes. Conclusão: o conteúdo de carga inorgânica e diferentes associações nas matrizes orgânicas interferiram expressivamente na fenda de contração de polimerização.

Palavras-chave: Resina Bulk Fill. Resinas compostas. Contração de polimerização.

\section{References}

1. Kim RJY, Kim YJ, Choi NS, Lee IB. Polymerization shrinkage, modulus, and shrinkage stress related to tooth-restoration interfacial debonding in Bulk Fill composites. J Dent 2015; 43:430-9.

2. Fronza BM, Rueggeberg FA, Braga RR, Mogilevych B, Soares LES, Martin AA et al.Monomer conversion, microhardness, internal marginal adaptation, and shrinkage stress of Bulk Fill composite resins. Dent Mater 2015; 31:1542-51.

3. Bacchi A, Dobson A, Ferracane JL, Consani R, Pfeifer CS. Thio-urethanes improve properties of dual-cured composite cements. J Dent Res 2014; 93:1320-5.

4. Barceleiro MO, Soares GM, Espindola O, Kahn S, Pola PI, Sampaio FH. Low-shrinkage composites: an in vitro evaluation of sealing ability after occlusal loading. Gen Dent 2014; 63:36-40.
5. Sakaguchi RL, Wiltbank BD, Shah NC. Critical configuration analysis of four methods for measuring polymerization shrinkage strain of composites. Dent Mater 2004; 20:388-96.

6. Ferracane JL, Hilton TJ. Polymerization stress-is it clinically meaningful? Dent Mater 2016; 32:1-10.

7. Zorzin J, Maier E, Harre S, Fey T, Belli R, Lohbauer U et al. Bulk Fill composite resins: polymerization properties and extended light curing. Dent Mater 2015; 31:293-301.

8. Emami N, Söderholm KJM. How light irradiance and curing time affect monomer conversion in light-cured composite resins. Eur J Oral Sci 2003; 111(6):536-42.

9. Boaro LC, Gonçalves F, Guimarães TC, Ferracane JL, Pfeifer CS, Braga RR. Sorption, solubility, shrinkage and mechanical properties of "low-shrinkage" commercial composite resins. Dent Mater 2013; 29:398-404.

10. Jang JH, Park SH, Hwang IN. Polymerization shrinkage and depth of cure of Bulk Fill composite resins and highly filled flowable resin. Oper Dent 2015; 40(2):172-80.

11. Al Sunbul H, Silikas N, Watts DC. Polymerization shrinkage kinetics and shrinkage-stress in dental resin-composites. Dent Mater 2016; 32:998-1006.

12. Gonçalves F, Kawano Y, Braga RR. Contraction stress related to composite inorganic content. Dent Mater 2010; 26: 704-9.

13. Han SH, Sadr A, Tagami J. Park S. Internal adaptation of composite resins at two configurations: influence of polymerization shrinkage and stress. Dent Mater 2016; 32(9): 1085-94.

14. El Damanhoury H, Platt J. Polymerization shrinkage stress kinetics and related properties of Bulk Fill composite resins. Oper Dent 2014; 39(4):374-382.

15. Toh WS, Yap AU, Lim SY. In Vitro Biocompatibility of Contemporary Bulk Fill Composites. Oper Dent 2015; 40(6): 644-52.

16. Al Sunbul H, Silikas N, Watts DC. Polymerization shrinkage kinetics and shrinkage-stress in dental resin-composites. Dent Mater 2016; 32:998-1006.

17. Haenel T, Hausnerová B, Steinhaus J, Price RB, Sullivan B, Moeginger B. Effect of the irradiance distribution from light curing units on the local micro-hardness of the surface of dental resins. Dent Mater 2015; 31:93-104.

18. Tsujimoto A, Barkmeier WW, Takamizawa T, Latta MA, Miyazaki M. Depth of cure, flexural properties and volumetric shrinkage of low and high viscosity Bulk Fill giomers and composite resins. Dent Mat 2017; 36:205-13

19. Braem M, Lambrechts P, Van Doren V, Vanherle G. The impact of composite structure on its elastic response. J Dent Res 1986; 65:648-53.

20. Rahiotis C, Kakaboura A, Loukidis M, Vougiouklakis G. Curing efficiency of various types of light-curing units. Eur $\mathrm{J}$ Oral Sci 2004; 112:89-94.

\section{Endereço para correspondência:}

Diala Aretha de Sousa Feitosa

Av. Maria Letícia Leite Pereira, 311, Lagoa Seca CEP: 63040-405, Juazeiro do Norte, CE, Brasil Telefones: (55) (88) 999288302, (55) (88) 35121772 E-mail: dialafeitosa@gmail.com

Recebido: 14/10/17. Aceito: 08/12/2017. 